\title{
Effect of Dental Bleaching on Marginal Sealing of Composite Resin Restorations Bonded with a Universal Adhesive
}

\author{
GIANINA IOVAN, CRISTINA ANGELA GHIORGHE*, SIMONA STOLERIU, GALINA PANCU, IRINA NICA, \\ IONUT TARABOANTA, SORIN ANDRIAN \\ Grigore T. Popa University of Medicine and Pharmacy lasi, Faculty of Dental Medicine,16 Universitatii Str., 700115, Iasi, Romania
}

\begin{abstract}
The aim of this study was to evaluate the postoperative effect of one bleaching agent containing $40 \%$ peroxide hydrogen on the interface between dental tissues and a microhybrid composite resin bonded with a universal adhesive applied in total-etch and self-etch technique. Standardized Class V restorations were performed in oral surfaces of 40 extracted human molars with the gingival margins placed bellow the cement-enamel junction. For 20 restorations the adhesive was applied with preliminary etching and for the others the adhesive was applied by using the self-etch technique. Half of the samples of each group were bleached using Opalescence Boost in one session 20 minutes-application. The sealing quality of both enamel and cervical margins of the restorations was evaluated using a microleakage test by immersion in $1 \%$ methylene blue for 24 hours. The microleakage scores were assessed using an optical microscope and the data were statistically analyzed. No statistical significant differences were recorded between the bleached and control groups and between the study groups according to the etching strategy used for bonding.
\end{abstract}

Keywords: microhybrid composite, methylene blue, dental caries, restorative dentistry

The increasing aesthetic demands of patients have led to the development of dental bleaching techniques. In order to achieve the bestresults in shorttime bleaching products with very high levels of active substance have been introduced on the market. How ever both clinical experience and experimental studies have shown that beyond the improvement of aesthetics, there are also side effects related primarily to post-operative sensitivity and pulp inflammation [1, 2]. One of the most important ways of preventing these complications is to treat all the caries and non-cariogenic defects with restorations prior to the bleaching procedures. Although old restorations and temporary fillings would be replaced afterwards because of their inappropriate shade, the quality of their sealing would be very important during bleaching and immediately after. It is also assumed that some of the posterior restorations would be preserved in spite of the differences of shade comparing to bleached adjacent enamel. Therefore, itis important to evaluate the effect of whitening on the adhesive junction between dental tissues and composite restorations.

The adverse effects of preliminary enamel bleaching on the adhesive junction have been well documented [36], however little information about the impact of postrestaurative whitening is available and the published data have been controversial by now [7].

The aim of this study was to assess the effect of a bleaching agent containing $40 \%$ hydrogen peroxide on the adhesive interface between the composite resin and dental tissues when a universal adhesive was used in either selfetch or total etch technique.

\section{Experimental part}

A total of 40 recently extracted intact molars were selected for this study. The teeth were cleaned by hand scaling and pumice, then stored in distilled water at $4^{\circ} \mathrm{C}$. V class cavities were prepared in the buccal surfaces using a cylindrical diamond bur with water spray and high speed. The dimensions of the cavities were $2 \mathrm{~mm}$ depth, $3 \mathrm{~mm}$ width and $2 \mathrm{~mm}$ high. All the margins of the cavities were prepared butt-joint in enamel. The gingival margins were prepared $1 \mathrm{~mm}$ beneath the enamel-cement junction. The cavities were cleaned with water and lightly air-dried using cotton pellets. The teeth were randomly distributed in 4 groups and restored with a light-cured microhybrid composite -Gradia Direct (shade A3) and a universal adhesive- G-Premio Bond (GC Corporation, Tokyo, Japan) as follows. In 2 groups the bonding system was applied using a total etch technique $(A, B)$; while in the other 2 groups the adhesive was applied using self-etch technique (C, D). For the first technique the margins and the walls of the cavities were etched using a gel containing 35\% phosphoric acid for $15 \mathrm{~s}$ prior to the application of the adhesive. Then the cavities were rinsed and gentle dried. The adhesive was applied on cavity walls for 10 seconds then dried thoroughly for $5 \mathrm{~s}$ and light cured for $10 \mathrm{~s}$ using a high power LED curing unit. The composite material was applied using the bulk technique and cured for $40 \mathrm{~s}$. For shaping the restoration, Mylar matrix were applied during polymerization. Each restoration was finished for approximately $10 \mathrm{~s}$ using a diamond extra-fine tapered bur (Mani Inc., Japan) and then ultra-fine straight-cut 30blades carbide bur (NTI Kahla GmbH, Germany) in order to simulate clinical procedures and remove any excess material at the restoration margins. The specimens were preserved in distilled water at $4^{\circ} \mathrm{C}$ for 30 days.

Groups $A$ and $C$ were used as control groups while the specimens in group $B$ and $D$ were subjected to bleaching procedures (table 1). The bleaching agent Opalescence Boost 40\% (Ultradent Products Inc.) was activated by pressing plunger 25 times each direction. The gel was applied for 20 min on the buccal surfaces of the teeth including restorations surfaces and at least $2 \mathrm{~mm}$ around the margins. The bleaching gel was thoroughly removed; the teeth were cleaned with water spray and stored in distilled water for another 24 hours.

Our study was done in accordance with the Ethical Committee regulations and in accordance to some published models [8-12]. 


\begin{tabular}{|l|l|l|l|l|l|}
\hline Group & $\begin{array}{l}\text { A } \\
\text { (control) }\end{array}$ & B & $\begin{array}{l}\text { C } \\
\text { (control) }\end{array}$ & D \\
\hline \begin{tabular}{l} 
Application $\begin{array}{l}\text { (conding system } \\
\text { bondef }\end{array}$ \\
\hline Bleaching
\end{tabular} & Total etch & $\checkmark$ & $\checkmark$ & & \\
\hline & Self etch & & & $\checkmark$ & $\checkmark$ \\
\hline
\end{tabular}

Table 1

CONTROL GROUPS AND STUDY GROUPS

The apices of all teeth were sealed with a self-adhering flowable composite resin (Vertise Flow- Kerr) and then the external surfaces of each sample were covered with two layers of nail varnish except for the restoration and a distance of about $1 \mathrm{~mm}$ around the tooth-restoration interface. The teeth were immersed in $1 \%$ methylene blue for $24 \mathrm{~h}$ and then washed under running water for $5 \mathrm{~min}$.

The teeth were axially sectioned in a buccal-lingual direction through the middles of the restorations. The images of the microleakages at the enamel margins and cervical margins were registered and scored using an optical Carl-Zeiss AXIO Imager Alm microscope, coupled with a high resolution digital camera, using Dark Field and Bright Field filters.

Dye penetration was evaluated according to a 4 point scale: 0 - no dye penetration; 1 - dye penetration from the cavosurface margin to less than half the length of the prepared wall; 2 - dye penetration from the cavosurface margin to more than half the length of the prepared wall, but not involving the axial wall; 3 - dye penetration from the cavosurface margin along the whole length of the prepared wall and also involving the axial wall. The scores were registered for each group and statistical analysis was performed using the non-parametric Mann-W hitney test.
Table 2

MICROLEAKAGE SCORES IN EACH GROUP

\begin{tabular}{|l|l|l|l|l|l|l|l|l|}
\hline \multirow{2}{*}{ Scores } & A & \multicolumn{1}{l|}{ B } & C & D \\
\cline { 2 - 9 } & Ae & Ac & Be & Bc & Ce & Cc & De & Dc \\
\hline $\mathbf{0}$ & 4 & 4 & 5 & 6 & 3 & 3 & 3 & 3 \\
\hline $\mathbf{1}$ & 6 & 3 & 4 & 2 & 7 & 7 & 5 & 4 \\
\hline $\mathbf{2}$ & - & 2 & 1 & 1 & - & - & 2 & 2 \\
\hline $\mathbf{3}$ & - & - & - & 1 & - & - & - & 1 \\
\hline
\end{tabular}

\section{Results and discussions}

The microleakage scores at enamel and cervical margins for all the groups are listed in table 2 and the mean values of the leakage scores and standard deviations are listed in table 3.

According to table 3 , the mean values of leakage scores for enamel were: $A(0.6)=B(0.6)<C(0.7)<D(0.9)$, while for dentin the increasing order was $A(0.7)=B(0.7)$ $=C(0.7)<D(1.1)$. For each group, the mean values of leakages scores tended to be higher for the cervical margins comparing to the enamel margins, except of control group $\mathrm{C}$, where there was the same mean score for both of the margins.

In both enamel and cervical margins within each group there were samples showing a satisfactory marginal sealing, with no sign of marginal leakage and samples

Table 3

MEAN VALUES OF MICROLEAKAGE SCORES AND STANDARD DEVIATIONS FOR EACH GROUP

\begin{tabular}{|c|c|c|c|c|c|c|c|c|c|c|c|}
\hline \multicolumn{6}{|c|}{ Enamel margins } & \multicolumn{6}{|c|}{ Cervical margin } \\
\hline & $\mathrm{N}$ & Minimum & Maximum & Mean & \begin{tabular}{|l|} 
Std. \\
Deviation
\end{tabular} & & $\mathrm{N}$ & Minimum & Maximum & Mean & \begin{tabular}{|l|} 
Std. \\
Deviation
\end{tabular} \\
\hline Ae & 10 & 0 & 1 & .60 & .516 & Ac & 10 & 0 & 2 & .70 & .823 \\
\hline $\mathrm{Be}$ & 10 & 0 & 2 & .60 & .699 & $\mathrm{Bc}$ & 10 & 0 & 3 & .70 & 1.059 \\
\hline $\mathrm{Ce}$ & 10 & 0 & 1 & .70 & .483 & $\mathrm{Cc}$ & 10 & 0 & 1 & .70 & .483 \\
\hline $\mathrm{De}$ & 10 & 0 & 2 & .90 & .738 & Dc & 10 & 0 & 3 & 1.10 & .994 \\
\hline $\begin{array}{ll}\text { Valid } & \mathrm{N} \\
\text { (listwise) }\end{array}$ & 10 & & & & & $\begin{array}{l}\text { Valid } \mathrm{N} \\
\text { (listwise) }\end{array}$ & 10 & & & & \\
\hline
\end{tabular}

\begin{tabular}{|c|c|c|c|}
\hline \multicolumn{4}{|c|}{ ENAMEL } \\
\hline $\mathbf{A}$ & B & $\mathrm{C}$ & D \\
\hline Score 0 & Score 1 & Score 1 & Score 2 \\
\hline \multicolumn{4}{|c|}{ DENTIN } \\
\hline $\mathbf{A}$ & B & $\mathrm{C}$ & D \\
\hline Score 2 & Score 0 & Score 2 & Score 3 \\
\hline
\end{tabular}

Fig. 1. Images of dye penetration between dental margins and composite resin 


\begin{tabular}{|c|c|}
\hline \multicolumn{2}{|l|}{ Test Statistics ${ }^{\mathrm{b}}$} \\
\hline & $\mathrm{Ae}-\mathrm{Be}$ \\
\hline Mann-Whitney U & 48.000 \\
\hline Wilcoxon W & 103.000 \\
\hline $\mathrm{Z}$ & -.171 \\
\hline Asymp. Sig. (2-tailed) & .865 \\
\hline Exact Sig. $\lceil 2 *(1$-tailed Sig. $)]$ & $.912^{\mathrm{a}}$ \\
\hline \multicolumn{2}{|l|}{ a. Not corrected for ties. } \\
\hline b. Grouping Variable: lot & \\
\hline
\end{tabular}

with various scores of stain infiltration (fig. 1). Score 3 showing a deep penetration involving the axial wall was found only in cervical margins, after bleaching procedures, while score 2 was found in enamel margins after bleaching procedure and in cervical margins with or without bleaching, with the exception of the control group $\mathrm{C}$.

Considering the low number of the specimens, we used the non-parametric Mann-Whitney test to determine if the differences were statistically significant.

When comparing the leakages scores at the enamel margins in the groups restored with preliminary acid etching, the values of the control group A tended to be slightly higher, how ever it was the group $B$ which recorded one score 2. Both groups registered the same mean score (0.6) and the differences were not statistically significant according to Mann-Whitney test ( $p=0.865>0.05)$. As regarding the comparison between the groups where selfetch technique was used, the values of leakages after bleaching (group D) tended to be higher than those of the control group $\mathrm{C}$ although the differences were not statistically significant $(p=0.543>0.05)$ (table 4$)$.

The values of cervical leakages when preliminary acid etching was used tended to be equal for the control group and bleached group, while for the self-etch groups the values of bleached group $D$ tended to be higher than the values of control group $C$, still the difference was not statistically significant ( $p=0.356>0.05$ ) (table 5$)$.

The leakage scores after bleaching at both enamel and cervical margins were compared according to the etching strategy and the results of statistical analyze are shown in table 6. At enamel margins the microleakages of Group D tended to have higher values than the Group $B$, however the difference was not statistically significant according to Mann-Whitney test $(p=0.344>0.05)$. The same tendency was observed for the cervical margins, the difference being also not statistically significant $(p=0.356$ $>0.05$ ).

Both composite resins and adhesive systems are susceptible to mechanical and chemical degradation in the oral environment $[13,14]$. Dental bleaching has

\begin{tabular}{|c|c|c|c|}
\hline \multicolumn{2}{|l|}{ Test Statistics $^{b}$} & \multicolumn{2}{|l|}{ Test Statistics $^{\mathrm{b}}$} \\
\hline & $\mathrm{Ac}-\mathrm{Bc}$ & & Cc-Dc \\
\hline Mann-Whitney U & 50.000 & Mann-Whitney U & 38.500 \\
\hline Wilcoxon W & 105.000 & Wilcoxon W & 93.500 \\
\hline$z$ & .000 & $z$ & -.923 \\
\hline Asymp. Sig. (2-tailed) & 1.000 & Asymp. Sig. (2-tailed) & .356 \\
\hline Exact Sig. $\lceil 2 *(1$-tailed Sig. $)\rceil$ & $1.000^{2}$ & Exact Sig. [2*(1-tailed Sig.)] & $.393^{\mathrm{a}}$ \\
\hline \multicolumn{2}{|l|}{ a. Not corrected for ties. } & \multicolumn{2}{|l|}{ a. Not corrected for ties. } \\
\hline \multicolumn{2}{|l|}{ b. Grouping Variable: lot } & \multicolumn{2}{|l|}{ b. Grouping Variable: lot } \\
\hline \multicolumn{2}{|l|}{ Test Statistics ${ }^{b}$} & \multicolumn{2}{|l|}{ Test Statistics ${ }^{b}$} \\
\hline & $\mathrm{Be}-\mathrm{De}$ & & Bc-Dc \\
\hline Mann-Whitney U & 38.500 & Mann-Whitney U & 38.500 \\
\hline Wilcoxon W & 93.500 & Wilcoxon W & 93.500 \\
\hline $\mathrm{Z}$ & -.946 & $z$ & -.923 \\
\hline Asymp. Sig. (2-tailed) & .344 & Asymp. Sig. (2-tailed) & .356 \\
\hline Exact Sig. $[2 *(1$-tailed Sig.) $]$ & $.393^{\mathrm{a}}$ & Exact Sig. [2*(1-tailed Sig.)] & $.393^{\mathrm{a}}$ \\
\hline \multicolumn{2}{|l|}{ a. Not corrected for ties. } & \multicolumn{2}{|l|}{ a. Not corrected for ties. } \\
\hline \multicolumn{2}{|l|}{ b. Grouping Variable: lot } & \multicolumn{2}{|l|}{ b. Grouping Variable: lot } \\
\hline
\end{tabular}

Table 5

RESULTS OF MANN-WHITNEY TEST. SIGNIFICANCE LEVEL OF COMPARISON BETWEEN EACH STUDY GROUP AND THE CORRESPONDING CONTROL GROUP FOR CERVICAL MARGINES
Table 6

RESULTSOF MANNWHITNEY TEST. SIGNIFICANCE LEVEL OF COMPARISON BETWEEN THE STUDY GROUPS FOR ENAMEL AND CERVICAL MARGINS 
become a routine procedure performed in dental office although highly-concentrated products could cause alterations of the surfaces of both enamel $[15,16]$ and composite resin $[17,18]$.

The active ingredients of commonly used bleaching agents include either hydrogen peroxide or carbamide peroxide in concentrations up to $40 \%$ hydrogen peroxide equivalent. The mechanisms of bleaching is based on releasing free radicals which attack the double bonds of chromophore molecules resulting in smaller, less heavily pigmented constituents [7, 19]. The oxygen radicals released from peroxide have a high nonspecific reactivity and therefore some effects are likely to occur on the adhesive joints between the dental tissues and the composite resin restorations.

In order to evaluate the safety of strong bleaching agents in terms of effects on the sealing ability of composite restorations, we chose to evaluate Opalescence Boost which contains the highest concentration of hydrogen peroxide accepted for in-office bleaching procedures ( $40 \%$ hydrogen peroxide). The whitening agent is activated by chemical reaction, and the material should be applied for 20 minutes, with the possibility of reapplication during the same session or during a further appointment.

The evaluation of the effects of bleaching on marginal sealing of composite restorations has produced contradictory results. Several studies reported that postoperative bleaching with 10-16\% carbamide peroxide adversely affect the marginal sealing in both enamel and dentin margins [20-22].

On the contrary our results showed that the microleakage scores were not significantly different after bleaching. These data are in accordance with the conclusions of several studies which evaluated the leakage of restorations when various bleaching systems had been used and found no differences when comparing with nonbleached samples. Bleaching with $20 \%$ carbamide peroxide for eight hours and $6 \%$ hydrogen peroxide for 30 min twice a day for 14 days did not affect the occlusal margins of the restorations [23]. Another study which evaluated in-office bleaching with 35\% hydrogen peroxide found no differences of leakage scores and similar Knoop hardness values of the bleached enamel located near the adhesive interface, concluding that bleaching did not damage the tooth-restoration interface of composite restorations [24]. Other studies on bleaching systems containing similar concentrations of hydrogen peroxide (30-38\%) produced congruent results. No significant increases of marginal leakage in both enamel and dentin after light activated or chemically activated bleaching products have been found $[25,26]$.

It was suggested that the effect of whitening on marginal leakage may vary depending on the bleaching method; how ever no difference was found for the chemically activated in-office bleaching products [27]. Assuming that most of the effects would be related to oxidation and corrosion phenomena, the limited exposure time used for in-office bleaching procedures might decrease the risk of detrimental effects on the interface between dental tissues and composite resin.

When comparing the etch-and-rinse and self-etch adhesive systems no significant differences were recorded [27], which also supports our findings. How ever our results showed an increasing tendency of the microleakage scores after bleaching for the group where self-etch technique had been used. Another study reported a small but significant increase of microleakage at the enamel margins of restorations applied with a self-etch adhesive and no significant differences for two other bonding systems after bleaching [28]. Dudek et al. also found that the durability of the adhesive joint was detrimentally influenced by carbamine peroxide bleaching, the simplified single-step self-etch adhesives being more sensitive to the bleaching. In our study the highest mean value of microleakage scores was recorded in the cervical margins after the bleaching of the restorations bonded without preliminary etching [29]. This is surprisingly if we consider the better quality of the interface observed in previous studies that evaluated the universal bonding systems applied in self-etch technique comparing to total etch technique [30-32]. The difference between the control group and the study group was not statistical significant, how ever itcould be clinical relevant since whitening agents are considered to be able to penetrate into the tooth structure through the unsealed dentin margin at the toothrestoration interface [3]. Moreover the cervical area might be subjected to morphological alterations during scaling and rootplanning procedures which mightlead to extensive areas of dentinal tubules denudations and scratches [33]. Therefore the deterioration of sealing during bleaching procedures involving these areas w ould probably produce complications like tooth hypersensitivity and microleakage. More research is needed to evaluate the impact of bleaching procedures on restored teeth when cervical area and root surfaces are involved. Whether bleaching is more detrimental to self-etch adhesives comparing to total etch systems should remain a research topic. In our study we tested a bleaching agent which is claimed to have buffers that help maintain a neutral $\mathrm{pH}$. This could be one of the reasons why we did not find higher leakage scores at the cervical margins for the total-etch technique despite the absence of the acid-base resistance zone.

Surprisingly one study reported that after application of $30 \%$ hydrogen peroxide, microleakage of nanofilled composite applied with a self-etch adhesive was reduced at the gingival margin compared to the control group while no significant difference was observed at the occlusal margin. However the authors found no significant differences for another methacrylate composite applied with the same adhesive in both occlusal and gingival margins [34].

It seems that the influence of whitening on marginal sealing of composite restorations would depend not only on the qualities of bleaching agent and bonding system butalso on the composite resin as well. Also the quality of the initially bonding could be more important than the chemical degradation induced by the bleaching gel.

This assumption is also supported by numerous studies that evaluated the effect of dental bleaching on the adhesive joint in terms of bond strength and the fracture toughness [4, 29, 35-38].

According to our study the tested bleaching system was safe to be used on restored teeth since it didn't show any significant influence on the sealing ability of the composite restorations performed with the tested materials. However this effect should be evaluated at least in terms of application time, repeated bleaching procedures and influence on aged restorations. Extensive research including other composite resins, bonding systems and bleaching agents would be necessary in order to clarify the impact of dental whitening on the sealing ability of composite restorations. 


\section{Conclusions}

The leakage scores of the composite restorations after bleaching with a whitening system containing $40 \%$ hydrogen peroxide were not significantly different comparing to the unbleached samples at both enamel and cervical margins.

The etching strategy used for bonding did not significantly influence the ability of the tested universal adhesive to seal the restorations margins after bleaching.

\section{References}

1.COSTA, C.A., RIEHL, H., KINA, J.F., SACONO, N.T., HEBLING, J. Oral Surg. Oral Med. Oral Pathol. Oral Radiol. Endod., 109, no. 4, 2010, e59-64. doi: 10.1016/j.tripleo.2009.12.002

2.VAZ, M.M., LOPES, L.G., CARDOSO, P.C., SOUZA, J.B., BATISTA, A.C., COSTA, N.L., TORRES, E.M., ESTRELA, C., J. Appl. Oral Sci., 24, no. 5, 2016, p. 509.

3.ATTIN, T., HANNIG, C., WIEGAND, A., ATTIN, R.., Dent. Mater., 20, no. 9, 2004, p.852.

4.CAVALLI, V., DE CARVALHO, R.M., GIANNINI, M., Braz. Oral. Res., 19, no. 1, 2005, p. 23.

5.BITTENCOURT, M.E., TRENTIN, M.S., LINDEN, M.S., DE OLIVEIRA LIMA ARSATI, Y.B., FRANCA, F.M., FLORIO, F.M., BASTING, R.T., J. Am. Dent. Assoc., 141, no.3, 2010, p.300.

6.BALAN, A., ANDRIAN, S., SAVIN, C., SANDU, A. V., PETCU, A., STOLERIU, S., Rev. Chim. (Bucharest), 66, no. 4, 2015, p. 562.

7.ALQUATANI, M.Q., Saudi. Dent. J., 26, no.2, 2014, p.33.

8.AGHEORGHIESEI CORODEANU, D.T., POROCH, V., 6th LUMEN International Conference on Rethinking Social Action Core Values, 16-19 April 2015, lasi, Romania, Rethinking Social Action. Core Values, p. 33.

9.TOADER, E., TOADER, T., Revista Romana de Bioetica, 10, no. 3, 2012, p. 66.

10.TOADER, E., Revista Romana de Bioetica, 8, no. 2, 2010, p. 157. 11.DOBRIN, R., CIOBICA, A., TOADER, E., POROCH, V., Rev. Chim. (Bucharest), 67, no. 9, 2016, p. 1778.

12.BALAN, G.G., TRIFAN, A., SAVIN, C., BALAN, A., GOLOGAN, E.. Revista de Cercetare si Interventie Sociala, 55, 2016, p. 244.

13.GHIORGHE, C.A., IOVAN, G., TOPOLICEANU, C., SANDU, A.V., ANDRIAN. S., Rev. Chim. (Bucharest), 64, no. 12, 2013, p.1436.

14.NICA, I., IOVAN, G., GHIORGHE, C.A., STOLERIU, S., PANCU, G., ANDRIAN, S., Mat. Plast., 51, 3, 2014, p. 282.

15.SA, Y., SUN, L., WANG, Z., MA, X., LIANG, S., XING, W., JIANG, T., WANG, Y., Oper. Dent., 38, no. 1, 2013, p. 100.

16.GRAZIOLI, G., VALENTE, L.L., ISOLAN, C.P., PINHEIRO, H.A., DUARTE, C.G., MUNCHOW, E.A., Arch. Oral Biol., 87, 2018, p. 157.
17.WATTANAPAYUNGKUL, P., YAP, A.U., CHOOI, K.W., LEE, M.F., SELAMAT, R.S., ZHOU, R.D., Oper. Dent., 28, no. 1, 2004, p. 15.

18.MUNTEANU, B., ANDRIAN, S., IOVAN, G., GHIORGHE, A., NICA, I., STOLERIU, S., Mat. Plast., 51, no. 3, 2014, p. 279.

19.MINOUX, M., SERFATY, R., Quintessence Int., 39, no. 8, 2008, p. 645.

20.CRIM, G.A., Am. J. Dent., 5, no.2, 1992, p. 109.

21.ULUKAPI, H., BENDERLI, Y., ULUKAPI, I., Quintessence Int., 34, no. 7, 2003, p. 505.

22.MOOSAVI, H., GHAVAMNASIRI, M., MANARI, V., The J ournal of Contemporary Dental Practice, 10, no. 6, 2009, E009-E016.

23.WHITE, D.J ., DUSCHNER, H., PIOCH, T., J. Clin. Dent., 19, no. 1, 2008, p. 33.

24.SILVA, L., THEDEI, G. JR., MENEZES-OLIVEIRA, M.A., NOGUEIRA, R.D., GERALDO-MARTINS V., Int. J. Esthet. Dent., 12, no. 1, 2017, p. 96. 25.KLUKOWSKA, M.A., WHITE, D.J., GIBB, R.D., GARCIA-GODOY, F., GARCIA-GODOY, C., DUSCHNER, H., J. Clin. Dent., 19, no. 1, 2008, p. 14.

26.KHOROUSHI, M., FARDASHTAKI, S.R., Oper. Dent., 34, 5, 2009, p. 565.

27.BEKTAS, 0.0., EREN, D., AKIN, C.G., SAG, B.U., OZCAN, M., Acta. Odontol. Scand., 71, no. 3-4, 2013, p.1000.

28.ROUBICKOVA, A., DUDEK, M., COMBA, L., HOUSOVA, D., BRADNA, P., Oper. Dent., 38, no. 6, 2013, p. 644.

29.DUDEK, M., ROUBICKOVA, A., COMBA, L., HOUSOVA, D., BRADNA, P., Oper. Dent., 38, no.4, 2013, p. 394

30.HANABUSA, M., MINE, A., KUBOKI, T., MOMOI, Y., VAN ENDE, A.,VAN MEERBEEK, B., DE MUNCK, J., J. DENT., 40, no. 6, 2012, p. 475.

31.IOVAN, G., STOLERIU, S., GHIORGHE, C.A., CIMPOESU, N., GEORGESCU, A., ANDRIAN, S., Mat. Plast., 51, no. 4, 2014, p. 421.

32.IOVAN, G., STOLERIU , S., ANDRIAN, A., International J ournal of Medical Dentistry, 7, no. 3, 2017, p. 189.

33.SOLOMON, S.M., TIMPU, D., AGOP FORNA, D., MARTU STEFANACHE, M.A., MARTU, S., STOLERIU, S., Mat. Plast., 53, no. 3, 2016, p. 546 34.HASHEMIKAMANGAR, S.S., GHAVAM, M., MAHINFAR, N., KHARAZI FARD M.J., J. Dent. (Tehran), 11, no. 5, 2014, p. 545.

35.BARCELLOS, D.C., BENETTI, P., FERNANDES JR., V.V., VALERA, M.C.,Oper. Dent. 35, no. 4, 2010, p. 463.

36.MOOSAVI, H., MOHAMMADIPOUR, H.S., GHAVAMNASIRI, M., ALIZADEH, S., Int. J. Biomater. 2015; 921425. doi: 10.1155/2015/921425. 37.GAVRILA, L., BALAN, A., MURARIU, A., SANDU, A. V., SAVIN, C., Rev. Chim. (Bucharest), 67, no. 11, 2016, p. 2228.

38.MIHALAS, E., MAXIM, A., BALAN, A., MATRICALA, L., MAXIM, D. C., TOMA, V., PETCU, A., Rev.Chim. (Bucharest), 66, no. 6, 2015, p. 843.

Manuscript received: 6.02 .2018 